\title{
The role of international trade on environmental efficiency: a DEA approach
}

\author{
Fatma Taskin*, Osman Zaim \\ Department of Economics, Bilkent University, Bilkent 06533, Ankara, Turkey
}

Accepted 14 January 2000

\begin{abstract}
The relationship between trade and environmental conditions receives considerable attention whenever countries are in the process of negotiating trade agreements. In this paper using a non-parametric non-stochastic production frontier approach, we first develop an environmental efficiency index for a sample of high income and low and middle income countries and then examine the role of trade on the changes in environmental efficiency. The paper shows that, in addition to the per capita income which exhibits an environmental Kuznets type relationship, trade-related variables such as trade composition, the share of polluting exports and openness of a country are important determinants of environmental efficiency. (c) 2001 Elsevier Science B.V. All rights reserved.
\end{abstract}

JEL classifications: Q32; Q25; F43

Keywords: Non-parametric frontiers; Environmental kuznets curve; International trade

\section{Introduction}

The issue of environmental regulation has been a major topic of debate in the recent free-trade agreements between nations. In addition to the spillover effects of environmental degradation and increased emphasis on global environmental conditions, the changes in international cost differentials and loss of relative

\footnotetext{
*Corresponding author. Tel.: +90-312-266-4137; fax: +90-312-266-5140.

E-mail address: taskin@bilkent.edu.tr (F. Taskin).
} 
competitive positions due to national pollution control and abatement policies are the reasons why the individuals of one country are concerned with the environmental problems of the other. However, the discussion on the relationship between trade and environmental conditions has not reached a consensus in the literature.

The debate on the effect of trade on environment concentrated on following two opposite views. One view claims that freer and increased trade will have detrimental effects on environmental conditions. The first concern of the proponents of this view is that, open trade may cause an overall decline in the international environmental standards when countries engage in competitive deregulation to alleviate the cost of environmental regulation. Less stringent environmental regulations in a country, distorts the relative cost of production across trading partners and creates comparative advantage in the production of polluting commodities which would lead to a specialization in exports of those goods. Another concern has been the migration of dirty industries to the countries where environmental policies are less restrictive. The re-location hypothesis elaborates on the possibility that environment regulations may have a dynamic influence on capital flows, giving incentive for polluting industries to migrate towards countries where environmental regulations are more lenient. Concerns were also raised that export led growth that results from free trade agreements can promote rapid and unsustainable extraction of natural resources and that increased production and trade volumes exacerbate the use of energy associated with the transportation of goods.

An alternative and more optimistic view on the relationship between trade and environment claims that an increase in trade will promote environmental quality in developing countries. Proponents of this view argue that, freer trade, by leading to a more efficient allocation and use of resources, permits countries to specialize in production of goods and services in which they possess a comparative advantage and hence resulting in the production of maximum level of output for a given level of energy and materials. A related argument emphasizes the ability of freer trade in increasing the financial resources available for environmental protection by promoting output expansion. This argument is further extended as a justification for the existence of an environmental Kuznets curve which states that there is a critical level of per capita income above which environmental quality increases.

Some of these hypothesized relationships are also tested empirically. For example, the issue that differential environmental standards may result in comparative disadvantage in countries with stringent environmental regulations and hence lead to relocation of the dirty industries to the countries with less stringent environmental rules has been tested by Pearson $(1985,1987)$ and Walter $(1982)$. Their results, however, have failed to support this hypothesized relationship. Furthermore, the adverse effect of high environmental standards on the competitiveness of industries has been rejected by the empirical studies of Benedickson et al. (1994), Pearce (1995) and Repetto (1995).

On the sequence of links between trade liberalization-growth-environmental quality there are numerous empirical evidence that freer trade promotes growth. As for the relationship between growth and environmental quality, Grossman and Krueger (1993, 1995) found an inverse U-type relationship between the scale of 
economic activity and environmental quality for a variety of pollutants ${ }^{1}$ except carbon dioxide. Similar conclusions are reached by Shafik and Bandyopadhyay (1992), Cropper and Griffith (1994), and Selden and Song (1994). However, for the pollutant carbon dioxide, there is almost common agreement that there exists a monotonic relationship between economic growth and carbon dioxide emissions.

The objective of this paper is to develop an environmental efficiency index for a sample of high income and low and middle income countries using non-parametric techniques and illustrate the impact of trade and its composition on environmental efficiency. In examining the determinants of environmental efficiency, we particularly concentrated on the effects of variables such as income, composition of exports, degree of openness and the share of polluting exports in total exports.

The paper is organized as follows: Section 2 presents the derivation of environmental efficiency indexes. Section 3 is allocated to the presentation of the data source and discussion of results. Finally Section 4 concludes.

\section{Model}

In the theory of production, it is common to assume that outputs are strongly disposable which implies that the disposal of any output can be achieved without incurring any cost in terms of reduced production of other outputs. However, the symmetric treatment of outputs in terms of their disposability characteristics looses its justification if one or some of the outputs produced are undesirable goods such as carbon dioxide $\left(\mathrm{CO}_{2}\right)$ along with a desirable output such as cement. Especially in regulated environments, where producing units are forced to clean up the undesirable outputs that they produce or forced to reduce their levels of undesirable output production, one has to treat undesirable and desirable outputs asymmetrically in terms of their disposability characteristics. Even in the absence of regulations, increased environmental consciousness in the society still requires the treatment of undesirable goods as weakly disposable, i.e. their disposal is achieved by reducing the desirable outputs proportionately.

The recognition that pollutants are not freely disposable and that some productive resources have to be given up to reduce the levels of undesirable outputs leads to the outcome of transforming the production process. Then, it is the extent of the required output sacrifice due to this transformation which determines the environmental efficiency and its improvement in a society.

The environmental efficiency indexes can be constructed by comparing the production processes under alternative assumptions on disposability. One such environmental efficiency index developed by Fare et al. (1989), introduces a hyperbolic graph efficiency approach. To explain the underpinnings of the method, one can use the figure below which represents the output sets for two piecewise

\footnotetext{
${ }^{1}$ These studies covered pollutants such as sulfur dioxide and suspended matter as a measure of air pollution and dissolved oxygen, fecal contamination and contamination by the heavy metals as indicators of water pollution.
} 


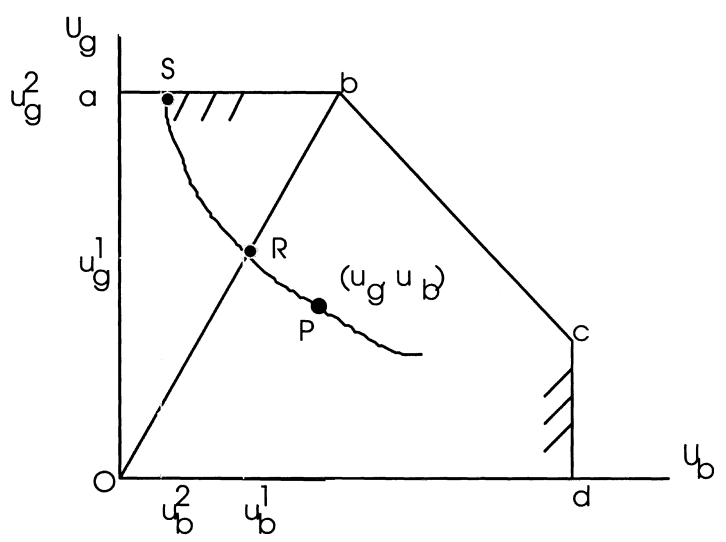

Fig. 1. Efficiencies with respect to strong and weakly disposable technologies.

linear technologies with different assumptions on disposability of undesirable outputs.

In Fig. 1, where $U_{g}$ and $U_{b}$ denote desirable output ('good') and undesirable output ('bad'), respectively, if the disposal of bad is costless, the line segment ab would be a feasible part of the technology since a reduction in $U_{b}$ (a movement from b towards a) would be possible without giving up any $U_{g}$. If, however, the disposal of $U_{b}$ is not costless the line segment ab will not be a feasible part of the technology. This is because some resources would be pulled out of the production of $U_{g}$ in order to clean up $U_{b}$ which in turn would imply production of Oa amount of $U_{g}$ is no longer feasible. Then, we say that the technology bounded by line segments $\mathbf{O a}, \mathbf{a b}, \mathbf{b c}$ and $\mathbf{c d}$ represents the strongly disposable output technology $P^{S}(x)$, and the technology bounded by line segments $\mathbf{O b}$, bc and cd represents technology with weakly disposable bads $P^{W}(x){ }^{2}$

To describe the theoretical background of the model used, suppose we observe a sample of $K$ production units, each of which uses inputs $x \in R_{+}^{N}$ to produce desirable outputs $y \in R_{+}^{M}$, and undesirable outputs $w \in R_{+}^{J}$. As a matter of notation let $x_{i}^{k}$ be the quantity of input $i$ used by unit $k$ and let $y_{i}^{k}$ and $w_{i}^{k}$ be the quantity of desirable and undesirable output $i$ produced by unit $k$, respectively. These data can be placed into data matrixes $\mathbf{M}$, a $K \times M$ matrix of desirable output levels whose $k, i$ th element is $y_{i}^{k}, \mathbf{J}$, a $K \times J$ matrix of undesirable output levels whose $k, i$ th element is $w_{i}^{k}$ and $\mathbf{N}$ a $K \times N$ matrix of input levels whose $k, i$ th element is $x_{i}^{k}$. Using the notation at hand and assuming that the production process satisfies strong disposability of both outputs (good and bad) and inputs, the constant returns to scale (CRS) output $\operatorname{set} P^{S}(x)$ (bounded by Oa, ab, bc and $\mathbf{c d}$ in

\footnotetext{
${ }^{2}$ Note here that we refrain from using the terminology 'weakly disposable output technology' since we still maintain strong disposability assumption on desirable output. The weakly disposable output technology would be bounded by $\mathbf{O b}$, bc, co (not drawn on the figure).
} 
Fig. 1) can be constructed from observed data by means of

$$
P^{S}(x):\left[(y, w): z^{T} \mathbf{M} \geq y, z^{T} \mathbf{J} \geq w, z^{T} \mathbf{N} \leq x, z \in R_{+}^{K}\right]
$$

where $z$ is a $K \times 1$ intensity vector. ${ }^{3}$ Similarly, a CRS technology satisfying the weak disposability of undesirable outputs and strong disposability of desirable outputs and inputs can be represented as an output set as shown below:

$$
P^{W}(x):\left[(y, w): z^{T} \mathbf{M} \geq y, z^{T} \mathbf{J}=w, z^{T} \mathbf{N} \leq x, z \in R_{+}^{K}\right] .
$$

Intuitively, these equations construct a reference technology from the observed inputs and outputs relative to which technical efficiency of each producing unit can be calculated. ${ }^{4}$ The next step in the construction of the environmental efficiency index is the computation of the opportunity cost of transforming the production process from one where all outputs are strongly disposable to the one which is characterized by weak disposability of undesirable outputs. Fare et al. (1989) define this opportunity cost as the ratio of two hyperbolic graph measures of technical efficiencies measured with respect to two technologies characterized by two different disposability assumptions. The hyperbolic graph measure of technical efficiency seeks the maximum simultaneous equiproportionate expansion for the desirable outputs and contraction for the inputs and undesirable outputs.

For a CRS technology which satisfies strong disposability of inputs and outputs (good or bad) hyperbolic graph measure of technical efficiency measure is defined as:

$$
F^{g}\left(x^{k^{\prime}}, y^{k^{\prime}}, w^{k^{\prime}}\right)=\min \left\{\lambda:\left(\lambda x^{k^{\prime}}, \lambda^{-1} y^{k^{\prime}}, \lambda w^{k^{\prime}}\right) \in G R\right\}
$$

and for each producing unit $k^{\prime}$ it can be computed as the solution to the following programming problem:

$$
\begin{aligned}
& F_{g}^{S}\left(x^{k^{\prime}}, y^{k^{\prime}}, w^{k^{\prime}}\right)=\min \lambda \quad F_{g}^{S}\left(x^{k^{\prime}}, y^{k^{\prime}}, w^{k^{\prime}}\right)=\min \Gamma \\
& \text { subject to } \\
& z^{T} M \geq \lambda^{-1} y^{k^{\prime}} \\
& z^{T} J \geq \lambda w^{k^{\prime}} \\
& z^{T} N \leq \lambda x^{k^{\prime}} \\
& \text { (LP1) or equivalently } Z^{T} J \geq \Gamma w^{k^{\prime}} \\
& z^{T} \in R_{+}^{K} \\
& \text { subject to } \\
& Z^{T} M \geq y^{k^{\prime}} \\
& Z^{T} N \leq \Gamma x^{k^{\prime}} \\
& Z^{T} \in R_{+}^{K}
\end{aligned}
$$

\footnotetext{
${ }^{3}$ The output set denotes the collection of all output vectors $y \in R_{+}^{M}$ and $w \in R_{+}^{J}$ that are obtainable from the input vector $x \in R_{+}^{N}$.

${ }^{4}$ Equivalently one may chose to define the reference set for a strongly disposable technology and for a weak disposable technology using a graph measure as $G R^{S}:\left[(x, y, w): z^{T} \mathbf{M} \geq y, z^{T} \mathbf{J} \geq w, z^{T} \mathbf{N} \leq x\right.$, $\left.z \in R_{+}^{K}\right]$ and $G R^{W}:\left[(x, y, w): z^{T} \mathbf{M} \geq y, z^{T} \mathbf{J}=w, z^{T} \mathbf{N} \leq x, \quad z \in R_{+}^{K}\right]$ respectively. The graph of the technology is the collection of all feasible input and output vectors.
} 
For computational purposes the non-linear programming problems (in LP1) are converted into linear programming problems as in (LP2), where $\Gamma=\lambda^{2}$ and $Z=\lambda z$ and the solution is derived by solving for $\sqrt{\Gamma}$. Note that, for any $\left(x^{k^{\prime}}, y^{k^{\prime}}, w^{k^{\prime}}\right) \in G R, F_{g}^{S}\left(x^{k^{\prime}}, y^{k^{\prime}}, w^{k^{\prime}}\right) \in(0,1]$ measures the maximum equiproportionate deflation of all inputs and undesirable outputs and inflation of all outputs that remain technically feasible.

For a technology that assumes weak disposability for the undesirable outputs and strong disposability for the desirable outputs and inputs, the following linear programming problem

$$
F_{g}^{W}\left(x^{k^{\prime}}, y^{k^{\prime}}, w^{k^{\prime}}\right)=\min \Omega
$$

subject to

$$
\begin{aligned}
& Z^{T} M \geq y^{k^{\prime}} \\
& Z^{T} J=\Omega w^{k^{\prime}} \\
& Z^{T} N \leq \Omega x^{k^{\prime}} \\
& Z^{T} \in R_{+}^{K}
\end{aligned}
$$

can be constructed to obtain a graph measure of technical efficiency for each producing unit $k^{\prime}$ as the solution to $\sqrt{\Omega}$. Finally the environmental efficiency index can be obtained from the ratio of these two efficiency scores as:

$$
H=\frac{\sqrt{\Gamma}}{\sqrt{\Omega}}
$$

Note that, this measure takes a value 1 only for those producing units which are on the segments bc and cd or for those producing units whose hyperbolic expansions fall on these segments. Since line segments bc and cd are common to both technologies with different assumptions on the disposability of bads, for those producing units, it is only natural to expect no opportunity cost of transforming the production process from one where all outputs are strongly disposable to the one which is characterized by weak disposability of undesirable outputs. For producing units whose $H$ index is less than 1 , the index indicates that there is an opportunity cost due to aforementioned transformation. The opportunity cost expressed in terms of the percentage of desirable output given up due to the reduced disposability of undesirable output, can be measured as $1-H$. Therefore $H$ index can safely be used as a measure of environmental efficiency.

The methods outlined above are applied to construct an environmental efficiency indexes for a group of high income and low and middle income countries for the years 1977, 1980, 1985 and 1990. The results are discussed in the following section. 
Table 1

Average environmental efficiency indexes

\begin{tabular}{llllll}
\hline Years & 1977 & 1980 & 1985 & 1990 & Average \\
\hline All countries & 0.9329 & 0.9238 & 0.9337 & 0.9271 & 0.9294 \\
High income & 0.9527 & 0.9497 & 0.9475 & 0.9553 & 0.9513 \\
Low and middle income & 0.9150 & 0.9007 & 0.9205 & 0.9024 & 0.9097 \\
\hline
\end{tabular}

\section{Data and discussion of results}

While computing the environmental efficiency indexes for each country (see Appendix A for the list of countries included in our analysis), we chose aggregate output measured by real Gross Domestic Product (GDP) expressed in international prices (in 1985 US dollar) as the desirable output and $\mathrm{CO}_{2}$ emissions (millions of tons) as the only undesirable output. The two inputs considered are aggregate labor input measured by the total employment and total capital stock. The input and the desirable output data are compiled from the Penn World Tables (PWT 5.6) initially derived from the International Comparison Program benchmark studies where cross country and overtime comparisons are possible in real values. Pollution related data are obtained from Carbon Dioxide Information Analysis Center.

To develop the environmental efficiency index, we used cross-section data on all countries to solve the linear programming problems (LP2) and (LP3) for each country. The solutions determine the efficiency of each country, for a given year, with respect to two world-multi-output production frontiers constructed under alternative disposability assumptions for the undesirable output. ${ }^{5}$ The ratio of these two efficiency scores renders the index of environmental efficiency for a given year. This computation is repeated for the years 1977, 1980, 1985 and 1990 to analyze the development of environmental efficiency overtime (see Table B2 in Appendix B). Table 1 presents a summary of the environmental efficiency indexes for countries grouped according to their income level. ${ }^{6}$ The mean environmental efficiency index for all countries, computed over the four years, is 0.9294 . From this figure, one can compute the opportunity cost of transforming the production process from one where all outputs (good or bad), are freely disposable to the one where pollution emissions are costly to dispose. This average opportunity cost expressed in terms of the average GDP is equal to $7.06 \%$ [ $(1-H)=0.0706]$.

These results show that there are differences in environmental efficiency among

\footnotetext{
${ }^{5}$ These show the percentage by which a producing unit can contract its resource use and emissions while simultaneously expanding its output and still remain in the respective feasible production sets. For instance the 0.9738 value computed for Argentina in year 1977 (see Table B1 in Appendix B), shows the factor by which the output can be expanded i.e. $U_{g} / 0.9738$ while simultaneously contracting the pollution emissions i.e. $U_{b} \times 0.9738$ and resource use, i.e. $x \times 0.9738$ and still remain in the feasible production set constructed by assuming strong disposability of pollutants.

${ }^{6} \mathrm{High}$ income and low and middle income country classifications are adopted from the World Bank classifications.
} 
the high income and the low and middle income countries. In accordance with the hypothesis of the environmental Kuznets curve, in terms of environmental efficiency, the high income group is found to be superior for all the selected years. However, in terms of developments over time no significant change has been observed in either of the groups.

The analysis of individual country experiences reveals that, averaged over 4 years, UK and USA in the high income group, and Morocco, Nigeria and $\mathrm{Yu}-$ goslavia in the low and middle income group have been fully efficient as measured by our environmental efficiency index. As for the poor performers one can identify New Zealand, Japan and Sweden in the high income and Sri Lanka, Madagascar and Panama in the middle and low income group with lowest average environmental efficiency scores (see Table B2 in Appendix B).

In examining the factors underlying the changes in the environmental efficiency, we expect that, specific attributes of an individual country contribute to the social and economic climate regarding environmental issues. One important attribute that influences the environmental concerns and hence environmental efficiency in a country, is the level of per capita income. Therefore, in explaining the environmental efficiency, the income variable which captures the environmental Kuznets relationship is a crucial variable. In addition to the income which captures the environmental Kuznets curve relationship, we focus on the impact of international trade on environmental efficiency. That is, the environmental efficiency changes which cannot be explained by the changes in income are hypothesized to be determined by trade related variables such as composition of exports, degree of openness and the share of polluting exports in total exports.

Letting $H_{i t}$ represent the environmental efficiency of country $i$ in year $t$, the equation below specifies a possible relation between the environmental efficiency and the variables discussed above

$$
\begin{gathered}
H_{i t}=\beta_{1}+\beta_{2} \mathrm{GDPPC}_{i t}+\beta_{3}\left(\mathrm{GDPPC}_{i t}^{2}+\beta_{4 j} \mathrm{EXP}_{j}+\beta_{5} \mathrm{POLEXP}_{i t}\right. \\
+\beta_{6}(\mathrm{POLEXP})_{i t}^{2}+\beta_{7} \mathrm{OPEN}_{i t}+\beta_{8}(\mathrm{OPEN})_{i t}^{2}+\varepsilon_{i t}
\end{gathered}
$$

where $i$, country index; $t$, time index; $\varepsilon$, disturbance term with mean zero and finite variance; GDPPC, GDP per capita; $\mathrm{EXP}_{j}$; dummy for export composition; POLEXP, the share of polluting export in total exports; and OPEN, openness index defined as the ratio of total exports and imports to GDP.

Of particular interest is the sign and significance of these coefficients. The environmental Kuznets relationship, which implies a deteriorating environmental performance at the initial phases of growth which is followed by an improvement once a critical level of per capita GDP is reached, can be depicted with a negative coefficient for GDPPC and a positive coefficient for its quadratic term. For the trade-related variables we have included one qualitative and two quantitative variables that will capture the impact of trade relations on the environmental efficiency. The qualitative variable is a set of intercept dummies which differentiates countries exhaustively according to their major export categories. In this 
respect World Development Report (1994) classifies countries according to five main categories as the exporters of manufactures, exporters of non-fuel primary products, exporters of fuels, exporters of services and countries with diversified exports. The significance of the coefficients of these variables will indicate if export composition has a determining effect on environmental efficiency. The two quantitative variables are the share of polluting exports ${ }^{7}$ in total exports and the degree of openness. The share of polluting exports will capture the change in environmental efficiency that stems from either having a comparative advantage in pollutionintensive commodities or being the recipient of the migration of dirty industries due to less restrictive environmental policies. ${ }^{8}$ A negative relationship is expected between environmental efficiency and share of polluting exports. The openness variable will show both the positive and the negative effects of increased volume of trade on the environmental efficiency. On the negative side it will account for such effects as the deterioration of the environment due to increased transportation that stems from increased volume of trade and on the positive side it captures the environmentally beneficial effects of harmonization of environmental policies which become a constraining factor as trade volume increases. The sign and the significance of the openness variable (and its quadratic term) will help us to select among the competing hypotheses on this issue.

The model is estimated as a fixed-effect model where country-specific effects are captured by five export-composition dummy variables. ${ }^{9}$ The estimation technique is ordinary least square (OLS) estimation using pooled data. Even though for a censored-dependent variable (the variables such as $H$ which is censored at 1.00) a Tobit estimation is recommended as a more appropriate technique, the use of this technique for fixed-effects model creates further complications. For a sample with a finite number of years, the Tobit model cannot consistently estimate the fixed effects and furthermore this inconsistency is transmitted to the estimates of $\beta \mathrm{s}$ and the estimated variance of $\varepsilon_{i t} \cdot{ }^{10}$ Hence OLS is a generally accepted estimation procedure in this setting.

Table 2 reports the parameter estimates of the model above for different income groups and the complete panel. The first column of the table reports the estima-

\footnotetext{
${ }^{7}$ Tobey (1990) identifies five pollution-intensive sectors which are mining, paper, chemicals, steel and metals, at three-digit SITC classification (see p. 193), which are not necessarily only manufacturing industries. These sectors are chosen due to high pollution abatement costs as percentage of total production costs. The fuel industry which was not included in Tobey (1990) is also considered as one other polluting export industry in this study.

${ }^{8}$ Note that a high share of polluting exports in total exports does not necessarily reveal information on a country's export orientation. For example two countries with similar share of polluting exports may belong to different export orientation categories. Alternatively, two countries in the same export orientation category may have different values for the share of polluting exports in total exports.

${ }^{9}$ In the estimation, the dummy variable for countries with diversified exports is excluded hence, the coefficients of the dummy variables represent the differential impact of having alternative export orientation.

${ }^{10}$ For a comprehensive discussion on limited dependent variables and panel data see Baltagi (1995), pp. $178-187$.
} 
tion results for the high income countries. ${ }^{11}$ For this regression equation, the variables GDPPC and its quadratic term are statistically significant and their respective signs imply a U-curve relationship between environmental efficiency and per capita income. This is actually another representation of the environmental Kuznets curve relationship. The initial deterioration of the environmental conditions and its improvement in latter stages of economic growth manifest itself as an initial decline and then an improvement of environmental efficiency once the threshold level of income of $\$ 11346$ has been reached.

For these high income countries, after accounting for the effect of income, we see that trade related variables generally have a significant impact on environmental efficiency. For example, while being a services exporter has a positive and significant impact, being exporters of manufactures has a significant negative impact on the environmental efficiency. The openness variable also exhibits a U-curve type quadratic relationship with the environmental efficiency. This is an indication that there is a threshold level of openness above which environmental efficiency increases. However, the regression results show that neither being the exporter of non-fuel primary products nor having polluting exports as a major part of total exports have a significant impact on environmental conditions.

The same exercise is also repeated for the group of low and middle income countries. The most striking result in these countries is the contradictory relationship between income and efficiency. As opposed to the Kuznets curve relationship found in high income countries, here we see improving environmental conditions with initial increases in income (up to the levels around \$4920) followed by a deterioration in environmental conditions. As for the qualitative variables of trade orientation, only the dummy variable for exporters of manufactures has a significant and positive impact on environmental efficiency. This relationship which is the opposite of what we observe in rich countries can be interpreted as the ability of low income countries to import clean technologies from high income countries while adopting export led growth strategies which mainly depend on exports of manufactures. ${ }^{12}$ Other trade related variables, openness and share of polluting exports in total exports, both exhibit a U-type relationship with environmental efficiency at significance levels below $10 \%$.

In the final estimation between environmental efficiency and related explanatory variables, all countries in the panel are considered. The conflicting quadratic

\footnotetext{
${ }^{11}$ The regression equation for the high income countries excludes the dummy variable for the fuel exporters since none of the high income countries are reported to be fuel exporters according to the World Development Report (1994).

${ }^{12}$ The differences in the signs and significances for the export orientation dummies in high income and low and middle income countries may also be attributed to the differences in the composition of goods in a given category. It may be the case that, after accounting for the differences in the share of polluting exports in total exports, the industries that are known to be relatively more labor intensive and environmentally friendly have a higher share in the total manufactured exports in low and middle income countries than their share in high income countries. Similarly the differences in the composition of the goods in the services category between the low and middle income and high income countries may affect the significance of the related coefficients.
} 
Table 2

Parameter estimates for alternative models ${ }^{\mathrm{a}, \mathrm{b}}$

\begin{tabular}{|c|c|c|c|}
\hline & $\begin{array}{l}\text { High income } \\
\text { countries }\end{array}$ & $\begin{array}{l}\text { Low and middle } \\
\text { income countries }\end{array}$ & All countries \\
\hline Constant & $\begin{array}{l}1.1190^{* *} \\
(30.008)\end{array}$ & $\begin{array}{c}0.8726^{* *} \\
(27.222)\end{array}$ & $\begin{array}{c}0.8442^{* *} \\
(41.418)\end{array}$ \\
\hline GDPPC & $\begin{array}{l}-2.63 \mathrm{E}-05^{* *} \\
(-3.727)\end{array}$ & $\begin{array}{l}6.16 \mathrm{E}-05^{* *} \\
(5.398)\end{array}$ & $\begin{array}{l}4.96 \mathrm{E}-05^{* *} \\
(7.668)\end{array}$ \\
\hline$(G D P P C)^{2}$ & $\begin{array}{l}1.04 \mathrm{E}-09^{* *} \\
(3.777)\end{array}$ & $\begin{array}{l}-6.26 \mathrm{E}-09^{* *} \\
(-4.655)\end{array}$ & $\begin{array}{l}-5.67 \mathrm{E}-09^{* *} \\
(-7.023)\end{array}$ \\
\hline$(G D P P C)^{3}$ & & & $\begin{array}{l}1.9 \mathrm{E}-13^{* *} \\
(6.555)\end{array}$ \\
\hline $\mathrm{EXP}_{\text {MAN }}$ & $\begin{array}{l}-0.0136^{* *} \\
(-2.573)\end{array}$ & $\begin{array}{c}0.0391^{* *} \\
(2.2738)\end{array}$ & $\begin{array}{r}-0.0027 \\
(-0.566)\end{array}$ \\
\hline $\mathrm{EXP}_{\mathrm{PRIM}}$ & $\begin{array}{l}-0.0152 \\
(-0.864)\end{array}$ & $\begin{array}{c}-0.0071 \\
(-0.554)\end{array}$ & $\begin{array}{l}-0.0051 \\
(-0.528)\end{array}$ \\
\hline $\mathrm{EXP}_{\mathrm{SER}}$ & $\begin{array}{l}0.0356^{* *} \\
(3.456)\end{array}$ & $\begin{array}{c}0.0214 \\
(1.1887)\end{array}$ & $\begin{array}{c}0.0126^{*} \\
(1.891)\end{array}$ \\
\hline $\mathrm{EXP}_{\mathrm{FUEL}}$ & & $\begin{array}{c}0.0484 \\
(1.384)\end{array}$ & $\begin{array}{c}0.0370 \\
(1.045)\end{array}$ \\
\hline POLEXP & $\begin{array}{c}-0.1504 \\
(-1.4627)\end{array}$ & $\begin{array}{l}-0.1650^{*} \\
(-1.820)\end{array}$ & $\begin{array}{l}-0.0121 \\
(-0.300)\end{array}$ \\
\hline$(\mathrm{POLEXP})^{2}$ & $\begin{array}{r}0.3936^{*} \\
(1.7481)\end{array}$ & $\begin{array}{c}0.1972^{*} \\
(1.815)\end{array}$ & $\begin{array}{c}0.0322 \\
(0.500)\end{array}$ \\
\hline OPEN & $\begin{array}{l}-0.0007^{* *} \\
(-2.377)\end{array}$ & $\begin{array}{l}-0.0015^{* *} \\
(-1.973)\end{array}$ & $\begin{array}{l}-0.0005^{*} \\
(-1.757)\end{array}$ \\
\hline$(\mathrm{OPEN})^{2}$ & $\begin{array}{l}3.46 \mathrm{E}-06^{* *} \\
(2.077)\end{array}$ & $\begin{array}{l}1.08 \mathrm{E}-05^{*} \\
(1.656)\end{array}$ & $\begin{array}{l}2.64 \mathrm{E}-06^{*} \\
(1.761)\end{array}$ \\
\hline \multicolumn{4}{|l|}{ Weighted statistics } \\
\hline Adjusted $R^{2}$ & 0.9971 & 0.9953 & 0.9986 \\
\hline$F$ statistic & 3535.6 & 2315.5 & 12623.45 \\
\hline$P$ value ( $F$-stat. $)$ & 0.0000 & 0.0000 & 0.0000 \\
\hline $\begin{array}{l}\text { Turning points for } \\
\text { GDP }\end{array}$ & $\$ 11346$ & $\$ 4920$ & $\begin{array}{l}\text { Max: } \$ 6629 \\
\text { Min: } \$ 12854\end{array}$ \\
\hline$N$ & 91 & 110 & 201 \\
\hline
\end{tabular}

${ }^{*}$ Indicates coefficients that are significant at $10 \%$ critical level.

** Indicates coefficients that are significant at $5 \%$ critical level.

${ }^{a}$ For all regression estimates the dummy variable for the countries with diversified exports are excluded from the model. Therefore the coefficient of the dummy variables included in the model shows the differential impact.

${ }^{\mathrm{b}}$ Numbers in parentheses are $t$ statistics.

relationship detected between environmental efficiency and income in the previous two regression equations (for the high income countries and for the low and middle income countries) compelled us to consider a third degree polynomial type relationship between these two variables. This polynomial relationship is found to be significant with environmental conditions improving up to a per capita income level $\$ 6630$. From this income level onwards the environmental efficiency declines until a new turning point of $\$ 12855$ per capita income, above which environmental 
conditions start to improve again. When all the countries are considered, only the countries whose export orientation is identified as services have significantly higher environmental efficiency compared to countries with other export orientation types. We observe significant U-type quadratic relationship between environmental efficiency and openness at significant levels below $10 \%$ as was the case when high income and low and middle income countries were analyzed separately. The impact of the polluting exports in total exports as an explanatory variable for environmental efficiency disappears when all countries are considered in one group.

Our results regarding the effect of trade-related variables on environmental efficiency are also supported by the conclusions of the previous empirical work. The weak significance of the share of polluting exports in total exports variable (POLEXP variables) is an indication that there is little propensity of pollution intensive industries to move to countries which tried to increase their comparative advantage using less restrictive environmental regulations. Similar findings are also reported by Grossman and Krueger (1993) who showed that even in industries with high pollution control costs, there are other obstacles to migration such as high fixed capital costs and high transportation expenses. Studies such as Kalt (1988), Tobey (1990) and Low and Yeats (1992), and also provided empirical evidence that cross-country differences in environmental standards are not an important determinant of international trade patterns. Hence, comparative advantage in pollution intensive industries is not expected to have any impact on environmental efficiency.

Another emphasis of our paper has been the analysis of whether export orientation has any significant impact on environmental efficiency. In this regard our results reveal the differential impact of having comparative advantage in manufactures on environmental efficiency across high income and low and middle-income countries. This is similar in spirit to the findings of Hettige et al. (1992) who points out that '... outward oriented, high-growth LDCs have slow growing or even declining toxic intensity of manufacturing...'. An OECD report explains this phenomena by the ability of dynamic and fast growing developing countries with the higher turnover rates of the manufacturing capital stock to invest more in new processes based on cleaner techniques.

This paper also provides empirical evidence on the interaction between the degree of openness and environmental performance. The significant parameter estimates of the quadratic relationship between the openness and environmental efficiency and their respective signs imply a deteriorating performance up to a certain level of openness and then an improving environmental performance once a threshold level is reached. This result provides support for both the pessimistic and the optimistic view on the effect of trade on environmental performance. The environmentally degrading effect of increased trade which may stem from increased transportation ${ }^{13}$ is more pronounced below a threshold level of openness. However, for countries that depend more on international trade, this negative

\footnotetext{
${ }^{13}$ For example Etkins et al. (1994) argue that '... trade contributes substantially to energy related environmental damage, such as carbon dioxide emissions and other air pollution.' since transportation which is a precondition for trade requires substantial amount of fossil fuel.
} 
influence seems to be offset by the environment improving effect of harmonization of environmental standards through signing and respecting international environmental treaties.

\section{Conclusion}

This paper, using non-parametric non-stochastic production frontier analysis, develops environmental efficiency indexes for the purpose of cross country and overtime comparisons. The particular emphasis is on the transformation of the technology to construct an environmental efficiency index. As opposed to methods which gauge the environmental quality with the levels of emissions of pollutants, the indexes that are derived in this study are based upon a production approach that differentiates between the disposability characteristics of the environmentally desirable and undesirable outputs. The closer inspection of this index reveals that after accounting for the effect of changes in per capita income level on environmental efficiency, there remains some variation in environmental efficiency that can be captured by trade related variables. Among the trade related variables considered, the variable that measures the degree of openness showed a significant impact on environmental efficiency for all alternative classifications. The countries whose export orientation is identified as services have significantly higher environmental efficiency compared to countries with other export orientation types when all the countries are analyzed in the same group.

\section{Appendix A:}

List of countries

High income

Australia

Belgium

Canada

Denmark

Finland

France

Germany, west

Hong Kong

Iceland

Ireland

Israel

Italy

Japan

Netherlands

New Zealand

Norway
Low and middle income

Argentina

Bolivia

Chile

Dominican Rep.

Ecuador

Greece

Guatemala

Honduras

India

Jamaica

Kenya

Korea, Rep.

Madagascar

Mexico

Morocco

Nigeria 


$\begin{array}{ll}\text { Portugal } & \text { Panama } \\ \text { Spain } & \text { Peru } \\ \text { Sweden } & \text { Phillippines } \\ \text { Switzerland } & \text { Sri Lanka } \\ \text { UK } & \text { Syria } \\ \text { USA } & \text { Thailand } \\ & \text { Turkey } \\ & \text { Venezuela } \\ & \text { Yugoslavia } \\ & \text { Zambia } \\ & \text { Zimbabwe }\end{array}$

\section{Appendix B}

Table B1

Efficency index with respect to strong and weak disposable technologies

\begin{tabular}{|c|c|c|c|c|c|c|c|c|}
\hline \multirow[t]{2}{*}{ Countries } & \multicolumn{4}{|c|}{$(\Gamma)^{-1 / 2}$} & \multicolumn{4}{|c|}{$(\Omega)^{-1 / 2}$} \\
\hline & 1977 & 1980 & 1985 & 1990 & 1977 & 1980 & 1985 & 1990 \\
\hline Argentina & 0.9738 & 0.9390 & 0.9047 & 0.8646 & 0.9927 & 0.9924 & 0.9100 & 0.8646 \\
\hline Australia & 0.9025 & 0.9276 & 0.9259 & 0.9079 & 0.9411 & 0.9545 & 0.9508 & 0.9296 \\
\hline Austria & 0.8837 & 0.8789 & 0.8420 & 0.8532 & 0.9212 & 0.9582 & 0.9383 & 0.9324 \\
\hline Belgium-Luxembourg & 0.9036 & 0.9359 & 0.9015 & 0.9324 & 0.9341 & 0.9510 & 0.9460 & 0.9777 \\
\hline Bolivia & 0.6955 & 0.6616 & 0.6913 & 0.6565 & 0.7952 & 0.8140 & 0.8152 & 0.7578 \\
\hline Canada & 0.9418 & 0.9520 & 0.9602 & 0.9669 & 0.9632 & 0.9664 & 0.9805 & 0.9865 \\
\hline Chile & 0.8636 & 0.9239 & 0.9076 & 0.8397 & 0.8712 & 0.9288 & 0.9148 & 0.8397 \\
\hline Colombia & 0.6789 & 0.6822 & 0.6956 & 0.6679 & 0.8063 & 0.8414 & 0.8049 & 0.7466 \\
\hline Denmark & 0.8226 & 0.8232 & 0.8465 & 0.8356 & 0.8763 & 0.8705 & 0.9009 & 0.8941 \\
\hline Dominican Rep. & 0.8862 & 0.9032 & 0.8593 & 0.7347 & 0.8866 & 0.9050 & 0.8686 & 0.7427 \\
\hline Ecuador & 0.7245 & 0.6848 & 0.6512 & 0.6023 & 0.9543 & 0.8607 & 0.7416 & 0.7088 \\
\hline Finland & 0.7739 & 0.8291 & 0.8376 & 0.8624 & 0.8269 & 0.8686 & 0.8997 & 0.9115 \\
\hline France & 0.8931 & 0.9197 & 0.8950 & 0.9086 & 0.9667 & 0.9805 & 0.9951 & 1.0000 \\
\hline Germany, west & 0.8929 & 0.9276 & 0.8982 & 0.8958 & 0.9311 & 0.9425 & 0.9273 & 0.9377 \\
\hline Greece & 0.7608 & 0.7613 & 0.7635 & 0.7732 & 0.7903 & 0.8180 & 0.7966 & 0.7848 \\
\hline Guatemala & 1.0000 & 1.0000 & 0.9629 & 0.8971 & 1.0000 & 1.0000 & 1.0000 & 1.0000 \\
\hline Honduras & 0.6972 & 0.6739 & 0.7354 & 0.6694 & 0.7556 & 0.8045 & 0.8059 & 0.8105 \\
\hline Hong Kong & 0.8251 & 0.8177 & 0.9788 & 1.0000 & 0.9325 & 1.0000 & 1.0000 & 1.0000 \\
\hline Iceland & 1.0000 & 1.0000 & 1.0000 & 0.9342 & 1.0000 & 1.0000 & 1.0000 & 0.9551 \\
\hline India & 0.6733 & 0.7102 & 0.8097 & 0.6692 & 0.7360 & 0.7871 & 0.8311 & 0.7731 \\
\hline Ireland & 0.8659 & 0.8541 & 0.8461 & 0.9502 & 0.8659 & 0.8650 & 0.8561 & 0.9502 \\
\hline Israel & 0.8327 & 0.8723 & 0.8850 & 0.9214 & 0.8709 & 0.9382 & 0.9179 & 0.9214 \\
\hline Italy & 0.8935 & 0.9412 & 0.9158 & 0.9404 & 0.9458 & 1.0000 & 1.0000 & 1.0000 \\
\hline Jamaica & 0.7561 & 1.0000 & 0.8155 & 1.0000 & 0.7563 & 1.0000 & 0.8155 & 1.0000 \\
\hline Japan & 0.7495 & 0.7602 & 0.7620 & 0.7844 & 0.7893 & 0.8479 & 0.8822 & 0.8639 \\
\hline Kenya & 0.6627 & 0.7322 & 0.8127 & 0.7772 & 0.7883 & 0.8706 & 0.9570 & 0.9998 \\
\hline Korea, Rep. & 0.7175 & 0.6769 & 0.7563 & 0.7827 & 0.7283 & 0.7090 & 0.7563 & 0.7859 \\
\hline Madagascar & 0.5815 & 0.6373 & 0.6413 & 0.5139 & 1.0000 & 1.0000 & 1.0000 & 1.0000 \\
\hline Mexico & 0.8794 & 0.9063 & 0.9064 & 0.9293 & 0.9216 & 0.9700 & 0.9064 & 0.9293 \\
\hline
\end{tabular}


Table B1 (Continued)

\begin{tabular}{|c|c|c|c|c|c|c|c|c|}
\hline \multirow[t]{2}{*}{ Countries } & \multicolumn{4}{|c|}{$(\Gamma)^{-1 / 2}$} & \multicolumn{4}{|c|}{$(\Omega)^{-1 / 2}$} \\
\hline & 1977 & 1980 & 1985 & 1990 & 1977 & 1980 & 1985 & 1990 \\
\hline Morocco & 0.9726 & 1.0000 & 1.0000 & 1.0000 & 0.9726 & 1.0000 & 1.0000 & 1.0000 \\
\hline Netherlands & 0.9503 & 0.9603 & 0.9257 & 0.9409 & 1.0000 & 0.9988 & 0.9903 & 0.9837 \\
\hline New Zealand & 0.8751 & 0.8812 & 0.8779 & 0.8433 & 0.9634 & 1.0000 & 0.9818 & 0.9104 \\
\hline Nigeria & 1.0000 & 1.0000 & 1.0000 & 1.0000 & 1.0000 & 1.0000 & 1.0000 & 1.0000 \\
\hline Norway & 0.8549 & 1.0000 & 1.0000 & 0.8919 & 0.9249 & 1.0000 & 1.0000 & 0.9276 \\
\hline Panama & 0.6088 & 0.6465 & 0.6525 & 0.5753 & 0.7587 & 0.8393 & 0.9408 & 0.7806 \\
\hline Peru & 0.7855 & 0.7532 & 0.7380 & 0.6362 & 0.8817 & 0.8659 & 0.8858 & 0.7765 \\
\hline Phillippines & 0.7314 & 0.7878 & 0.7241 & 0.7167 & 0.7318 & 0.7970 & 0.7714 & 0.8061 \\
\hline Portugal & 0.8863 & 0.8664 & 0.8703 & 0.9300 & 0.9151 & 0.9108 & 0.8786 & 0.9300 \\
\hline Spain & 0.9345 & 0.9003 & 0.8747 & 0.9068 & 0.9390 & 0.9446 & 0.9239 & 0.9526 \\
\hline Sri Lanka & 0.5430 & 0.5670 & 0.6472 & 0.5791 & 1.0000 & 1.0000 & 1.0000 & 1.0000 \\
\hline Sweden & 0.8660 & 0.8857 & 0.8857 & 0.8787 & 0.9310 & 0.9559 & 0.9995 & 0.9990 \\
\hline Switzerland & 0.9264 & 0.9655 & 0.9400 & 0.9446 & 1.0000 & 1.0000 & 1.0000 & 1.0000 \\
\hline Syria & 0.9302 & 0.8917 & 0.8666 & 0.8327 & 1.0000 & 1.0000 & 0.9089 & 0.8327 \\
\hline Thailand & 0.7183 & 0.7435 & 0.7697 & 0.7792 & 0.7662 & 0.7919 & 0.7957 & 0.8151 \\
\hline Turkey & 0.7817 & 0.7239 & 0.7762 & 0.7758 & 0.7917 & 0.7685 & 0.7826 & 0.7758 \\
\hline UK & 0.9547 & 0.9293 & 1.0000 & 0.9884 & 0.9547 & 0.9293 & 1.0000 & 0.9884 \\
\hline USA & 1.0000 & 1.0000 & 1.0000 & 1.0000 & 1.0000 & 1.0000 & 1.0000 & 1.0000 \\
\hline Venezuela & 1.0000 & 0.8955 & 0.8308 & 0.8348 & 1.0000 & 0.9327 & 0.8490 & 0.8348 \\
\hline Yugoslavia & 1.0000 & 1.0000 & 1.0000 & 0.9787 & 1.0000 & 1.0000 & 1.0000 & 0.9787 \\
\hline Zambia & 0.6356 & 0.6866 & 0.7470 & 0.6703 & 0.6356 & 0.7139 & 0.8041 & 0.8252 \\
\hline Zimbabwe & 0.4615 & 0.4923 & 0.5658 & 0.5060 & 0.5010 & 0.5277 & 0.5785 & 0.5194 \\
\hline
\end{tabular}

Table B2

$H$ index (environmental efficiency index)

\begin{tabular}{llllll}
\hline $\begin{array}{l}\text { Countries } \\
\text { All countries }\end{array}$ & 1977 & 1980 & 1985 & 1990 & $\begin{array}{l}\text { Average } \\
0.9294\end{array}$ \\
\hline High income & 0.9329 & 0.9238 & 0.9337 & 0.9271 & \\
\hline Australia & 0.9527 & 0.9497 & 0.9475 & 0.9553 & 0.9513 \\
Austria & 0.9589 & 0.9719 & 0.9738 & 0.9767 & 0.9703 \\
Belgium & 0.9593 & 0.9172 & 0.8974 & 0.9150 & 0.9222 \\
Canada & 0.9673 & 0.9841 & 0.9529 & 0.9536 & 0.9645 \\
Denmark & 0.9778 & 0.9851 & 0.9792 & 0.9802 & 0.9806 \\
Finland & 0.9386 & 0.9456 & 0.9396 & 0.9346 & 0.9396 \\
France & 0.9356 & 0.9545 & 0.9310 & 0.9462 & 0.9419 \\
Germany, west & 0.9239 & 0.9380 & 0.8994 & 0.9086 & 0.9175 \\
Hong Kong & 0.9590 & 0.9842 & 0.9686 & 0.9554 & 0.9668 \\
Iceland & 0.8848 & 0.8177 & 0.9788 & 1.0000 & 0.9203 \\
Ireland & 1.0000 & 1.0000 & 1.0000 & 0.9782 & 0.9945 \\
Israel & 1.0000 & 0.9875 & 0.9884 & 1.0000 & 0.9940 \\
Italy & 0.9562 & 0.9298 & 0.9642 & 1.0000 & 0.9625 \\
Japan & 0.9447 & 0.9412 & 0.9158 & 0.9404 & 0.9355 \\
Netherlands & 0.9496 & 0.8966 & 0.8638 & 0.9079 & 0.9045 \\
& 0.9503 & 0.9615 & 0.9348 & 0.9565 & 0.9508
\end{tabular}


Table B2 (Continued)

\begin{tabular}{|c|c|c|c|c|c|}
\hline $\begin{array}{l}\text { Countries } \\
\text { All countries }\end{array}$ & $\begin{array}{l}1977 \\
0.9329\end{array}$ & $\begin{array}{l}1980 \\
0.9238\end{array}$ & $\begin{array}{l}1985 \\
0.9337\end{array}$ & $\begin{array}{l}1990 \\
0.9271\end{array}$ & $\begin{array}{l}\text { Average } \\
0.9294\end{array}$ \\
\hline $\begin{array}{l}\text { New Zealand } \\
\text { Norway } \\
\text { Portugal } \\
\text { Spain } \\
\text { Sweden } \\
\text { Switzerland } \\
\text { UK } \\
\text { USA }\end{array}$ & $\begin{array}{l}0.9083 \\
0.9243 \\
0.9685 \\
0.9952 \\
0.9302 \\
0.9264 \\
1.0000 \\
1.0000\end{array}$ & $\begin{array}{l}0.8812 \\
1.0000 \\
0.9512 \\
0.9531 \\
0.9265 \\
0.9655 \\
1.0000 \\
1.0000\end{array}$ & $\begin{array}{l}0.8942 \\
1.0000 \\
0.9906 \\
0.9468 \\
0.8861 \\
0.9400 \\
1.0000 \\
1.0000\end{array}$ & $\begin{array}{l}0.9263 \\
0.9615 \\
1.0000 \\
0.9519 \\
0.8795 \\
0.9446 \\
1.0000 \\
1.0000\end{array}$ & $\begin{array}{l}0.9025 \\
0.9715 \\
0.9776 \\
0.9617 \\
0.9056 \\
0.9441 \\
1.0000 \\
1.0000\end{array}$ \\
\hline $\begin{array}{l}\text { Low and middle } \\
\text { income }\end{array}$ & 0.9150 & 0.9007 & 0.9205 & 0.9024 & 0.9097 \\
\hline $\begin{array}{l}\text { Argentina } \\
\text { Bolivia } \\
\text { Chile } \\
\text { Colombia } \\
\text { Dominican Rep. } \\
\text { Ecuador } \\
\text { Greece } \\
\text { Guatemala } \\
\text { Honduras } \\
\text { India }\end{array}$ & $\begin{array}{l}0.9809 \\
0.8746 \\
0.9913 \\
0.8420 \\
0.9996 \\
0.7592 \\
0.9627 \\
1.0000 \\
0.9227 \\
0.9147\end{array}$ & $\begin{array}{l}0.9462 \\
0.8128 \\
0.9947 \\
0.8109 \\
0.9981 \\
0.7956 \\
0.9307 \\
1.0000 \\
0.8376 \\
0.9024\end{array}$ & $\begin{array}{l}0.9942 \\
0.8480 \\
0.9921 \\
0.8642 \\
0.9893 \\
0.8781 \\
0.9585 \\
0.9629 \\
0.9125 \\
0.9743\end{array}$ & $\begin{array}{l}1.0000 \\
0.8664 \\
1.0000 \\
0.8946 \\
0.9892 \\
0.8498 \\
0.9852 \\
0.8971 \\
0.8258 \\
0.9044\end{array}$ & $\begin{array}{l}0.9803 \\
0.8504 \\
0.9945 \\
0.8529 \\
0.9940 \\
0.8207 \\
0.9593 \\
0.9650 \\
0.8747 \\
0.9239\end{array}$ \\
\hline $\begin{array}{l}\text { Jamaica } \\
\text { Kenya } \\
\text { Korea, Rep } \\
\text { Madagascar } \\
\text { Mexico } \\
\text { Morocco } \\
\text { Nigeria } \\
\text { Panama } \\
\text { Peru } \\
\text { Philippines } \\
\text { Sri Lanka } \\
\text { Syria } \\
\text { Thailand } \\
\text { Turkey } \\
\text { Venezuela } \\
\text { Yugoslavia } \\
\text { Zambia } \\
\text { Zimbabwe }\end{array}$ & $\begin{array}{l}0.9998 \\
0.8407 \\
0.9851 \\
0.5815 \\
0.9542 \\
1.0000 \\
1.0000 \\
0.8024 \\
0.8909 \\
0.9994 \\
0.5430 \\
0.9302 \\
0.9375 \\
0.9873 \\
1.0000 \\
1.0000 \\
1.0000 \\
0.9212\end{array}$ & $\begin{array}{l}1.0000 \\
0.8410 \\
0.9547 \\
0.6373 \\
0.9344 \\
1.0000 \\
1.0000 \\
0.7703 \\
0.8699 \\
0.9885 \\
0.5670 \\
0.8917 \\
0.9388 \\
0.9419 \\
0.9601 \\
1.0000 \\
0.9618 \\
0.9328\end{array}$ & $\begin{array}{l}1.0000 \\
0.8492 \\
1.0000 \\
0.6413 \\
1.0000 \\
1.0000 \\
1.0000 \\
0.6936 \\
0.8331 \\
0.9387 \\
0.6472 \\
0.9534 \\
0.9673 \\
0.9918 \\
0.9786 \\
1.0000 \\
0.9290 \\
0.9780\end{array}$ & $\begin{array}{l}1.0000 \\
0.7774 \\
0.9959 \\
0.5139 \\
1.0000 \\
1.0000 \\
1.0000 \\
0.7371 \\
0.8193 \\
0.8891 \\
0.5791 \\
1.0000 \\
0.9560 \\
1.0000 \\
1.0000 \\
1.0000 \\
0.8123 \\
0.9742\end{array}$ & $\begin{array}{l}0.9999 \\
0.8271 \\
0.9839 \\
0.5935 \\
0.9721 \\
1.0000 \\
1.0000 \\
0.7508 \\
0.8533 \\
0.9539 \\
0.5841 \\
0.9438 \\
0.9499 \\
0.9803 \\
0.9847 \\
1.0000 \\
0.9258 \\
0.9515\end{array}$ \\
\hline
\end{tabular}

\section{References}

Baltagi, B.H., 1995. Econometrics Analysis of Panel Data. John Wiley \& Sons.

Benedickson, J., Doern, G.B., Olewiler, N., 1994. Getting the Green Light: Environmental Regulations and Investment in Canada, Toronto, Canada, C.D. Howe Institute Policy Study 22. 
Carbon Dioxide Information Analysis Center, Oak Ridge National Laboratory, Marland G. and Boden T., http://cdiac.ESD.ORNL.gov

Cropper, M., Griffith, C., 1994. The Interaction of Population Growth and Environmental Quality, AEA Papers and Proceedings, May, pp. 250-254.

Etkins, P., Folke, C., Costanza, R., 1994. Trade, environment and development: the issues in perspective. Ecol. Econ. 9, 1-12.

Fare, R., Grosskopf, S., Lovell, C.A.K., Pasurka, C., 1989. Multilateral productivity comparisons when some outputs are undesirable. Rev. Econ. Stat. 71, 90-98.

Grossman, G.M., Krueger, A.B., 1993. Environmental impacts of a North American free trade agreement. In: Garber, A. (Ed.), The Mexico-US Free Trade Agreement. MIT Press, Cambridge, MA.

Grossman, G.M., Krueger, A.B., 1995. Economic growth and the environment. Q. J. Econ. May, 353-377.

Hettige, H., Lucas, R.E.B., Wheeler, D., 1992. The Toxic Intensity of Industrial Production: Global Patterns, Trends, and Trade Policy, AEA Papers and Proceedings, May, pp. 478-481.

Kalt, J.P., 1988. The impact of domestics environmental regulatory policies on US international competitiveness. In: Spence, A.M., Hazard, H.A. (Eds.), International Competitiveness. Bellinger, Cambridge, MA.

Low, P., Yeats, A., 1992. Do 'dirty' industries migrate. In: Low, P. (Ed.), International Trade and Environment. World Bank, Washington, DC.

OECD Future Liberalization of Trade in Environmental Goods and Services: Ensuring Environmental Protection as Well as Economic Benefits, Joint Working Party on Trade and Environment, COM/ENV(98)37/FINAL.

Pearce, D., 1995. The greening of the GATT: some economics considerations. In: Cameron, J., Demaret, P., Geradin, D. (Eds.), Trade and Environment: The Search for Balance, London Cameron, May.

Pearson, C., 1985. Down to Business: Multinational Corporations, Environment and the Third World. Duke Univ. Press, Durham.

Pearson, C. (Ed.), 1987. Multinational Corporation, the Environment an Development, World Resources Institute, Washington, DC.

Repetto, R., 1995. Jobs, Competitiveness and Environmental Regulation: What are the real issues? World Resources Institute, Washington, DC.

Selden, T., Song, D., 1994. Environmental quality and development: is there a Kuznets curve for air pollution emissions? J. Environ. Econ. Manage. 27, 147-162.

Shafik, N., Bandyopadhyay, S., 1992. Economic Growth And Environmental Quality: Time Series And Cross Country Evidence, World Bank Policy Research Working Paper, WPS 904, World Bank, Washington, DC.

Tobey, J., 1990. The Effect of domestic environmental policies on patterns of world trade. Kyklos 43.2, 191-209.

Walter, I., 1982. Environmentally induced industrial relocation to developing countries. In: Rubin, S.J., Graham, T.R. (Eds.), Environment and Trade. Osmun and Co. Publishers, Allanheld, pp. 67-101.

World Development Report, 1994. The World Bank, Oxford University Press, New York, NY. 